\section{Etnografia, pamięć, eksperyment: w stronę alternatywnej historii społecznej}

Tomasz Rakowski
Tekst został przygotowany na podstawie prac badawczych realizowanych w ramach grantu Narodowego Centrum Nauki $\mathrm{nr} 2012 / 05 / \mathrm{D} / \mathrm{HS} 2 / 03639$.

TEKSTY DRUGIE 2016, NR 6, S. 268-281

DOI: 10.18318/td.2016.6.15

$\mathbf{W}$ polskiej pamięci zbiorowej zawartej w przekazach publicystycznych, dziennikarskich czy akademickich pojawia się nieustannie wrażenie, że środowiska bardziej peryferyjne, takie jak mieszkańcy wsi, nowe grupy robotników i migrantów zarobkowych, nie wnoszą do świadomości historycznej własnych form rozumienia przeszłości. Ten stosunek do ludzi działających poza głównym nurtem środowisk publicystycznych w szczególny sposób wydobywa jednak ukryte napięcia i tlące się wciąż konflikty społeczne. Choć problemy te obecne są od dawna, to ich historia wciąż dla wielu pozostaje niewidoczna. Jest ona związana z pewnym syndromem wstydu społecznego, głęboko tkwiącego w Polakach, przy czym doświadczenie to wyrasta obecnie głównie z czasów PRL-u i jest w dużym stopniu doświadczeniem masowych migracji do miast $\mathrm{i}$ transformującej się już wtedy tkanki społecznej, o czym pisałem dokładniej niedawno na łamach „Tekstów Drugich”. To olbrzymie

1 T. Rakowski Sztuka w przestrzeniach wiejskich i eksperymenty etnograficzne. Pożegnanie kultury zawstydzenia: jednoczasowość, zwrot ku sobie, proto-socjologia , "Teksty Drugie” 2016 nr 4.
Tomasz Rakowski etnolog, antropolog kultury, kulturoznawca, lekarz. Adiunkt w Instytucie Etnologii i Antropologii Kulturowej UW, współpracuje z Instytutem Kultury Polskiej UW. Zajmuje się antropologicznymi badaniami ubóstwa, badaniami oddolnych procesów rozwojowych, antropologią sztuki współczesnej i partycypacyjnej, etnograficznie zorientowaną animacją kultury oraz najnowszą metodologią badań kulturowych. Autor książki Łowcy, zbieracze, praktycy niemocy. Etnografia człowieka zdegradowanego (2009). 
przemieszczenie, odkryte po raz kolejny kilka lat temu wraz z publikacjami, Andrzeja Ledera², a wcześniej obecne chociażby w tezach Jacka Wasilewskiego ${ }^{3}$, wskazujących na klasę średnią jako w większości wywodzącą się $\mathrm{z}$ wiejskich migrantów, staje się miejscem narodzin wielu „inteligenckich" form pamięci, obciążających niewidoczne społeczeństwo pewnym defektem, pewną niekompetencją czy jeszcze mocniej - niedojrzałością kulturową. Jest to więc nic innego jak forma pamięci dominującej, zachowującej prawo do oceny i interpretacji, budującej obrazy całych grup (ludzi migrujących do miast ze środowisk wiejskich) jako środowisk pełnych niechęci do instytucji, do państwa, do dbania o dobro wspólne, za to przesiąkniętych ciasnymi, grupowymi egoizmami i skłonnością do gromadzenia dóbr materialnych.

Pamięć lat PRL-u związana z analizami socjologicznymi jest tu jednak też punktem wyjścia. W analizach tych znaleźć można opisy społeczeństwa jako zbiorowości złożonej zamkniętych grup rodzinno-krewniaczych, dzielących się na przykład przywilejami i nielegalnymi dostępami do różnego rodzaju dóbr wynoszonych z fabryk, z hal produkcyjnych, co było jednocześnie uspra-

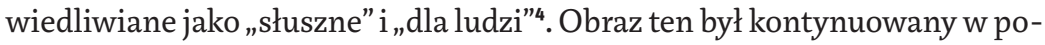
staci socjologicznej rekonstrukcji pewnej „próżni” czy „anomii” społecznej: chodziło tu o wskazanie, że w latach PRL-u w małych grupach często nielegalnie i nieformalnie uzyskiwano korzyści dla najbliższych kręgów, co było jednocześnie pewną wartością. Podobnie pisano o kontynuacji w latach 90. silnych związków wewnątrz wiejskich i wiejsko-robotniczych grup kierują-

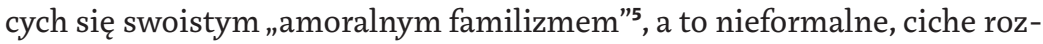
wiązywanie problemów z pracą i utrzymaniem przywilejów w ciasnym kręgu rodziny czy nawet w małej, na przykład sąsiedzko-rodzinnej, grupie w wielu przypadkach uznawano za postawę absolutnie przeciwstawną „właściwie”

2 A. Leder Prześniona rewolucja.Ćwiczenia zlogiki historycznej, Wydawnictwo Krytyki Politycznej, Warszawa 2013.

3 J. Wasilewski Społeczeństwo polskie, społeczeństwo chłopskie, "Studia Socjologiczne" $1986 \mathrm{nr} 3$, s. 40-56; Jesteśmy potomkami chłopów. Z prof. Jackiem Wasilewskim rozmawia M. Duch-Dyngosz, "Inak" $2012 \mathrm{nr} 684$.

4 M. Tymiński Funkcjonowanie klik w zakładach przemysłowych (1950-1970), „Kultura i Społeczeństwo" 2002 nr 4, s. 109-131.

5 E. Tarkowska, J. Tarkowski „Amoralny familizm”, czyli o dezintegracji społecznej w Polsce lat osiemdziesiątych, w: Władza i społeczeństwo w systemie autorytarnym, red. J. Tarkowski, IFiS PAN, Warszawa 1994, s. 263-281. 
funkcjonującemu społeczeństwu. To przede wszystkim te nieformalne, zażyłe grupy ludzi trafiających z przeludnionych wsi do zakładów przemysłowych i do okołoprzemysłowych osiedli stawały się w publicystycznych i socjologizujących dyskursach odpowiedzialne za niewłaściwe przemiany, za powstawanie obecnych struktur społeczeństwa, w którym dominują negatywne „residua systemowe".

\section{Inne spojrzenie: oddolne praktyki, samoorganizacja}

Jeśli jednak spojrzymy uważnie na historię społeczną, a szczególnie historię społeczną wsi pod koniec lat 6o. i w latach 70., to dostrzeżemy, że jest to czas z wielu powodów niezwykle ważny dla ludzi. To moment zluzowania obowiązkowych kontyngentów i dostaw żywności, okres względnie sensownego funkcjonowania kółek rolniczych i ośrodków maszynowych, wprowadzenia na początku lat 70. rent i emerytur, w tym za zdaną na rzecz państwa ziemię7. W tym wszystkim pojawiają się elementy wspólnoty - działają ochotnicze straże pożarne, dużo jest nieformalnych spotkań, „posiad” sąsiedzkich, sobotnich zabaw, organizacji wiejskich świąt. Co więcej, mamy też wtedy na wsi do czynienia z powszechnym stawianiem domów i budynków gospodarczych. Mieszkańcy wsi - ludzie po szkołach budowlanych, pracujący w miastach na budowach i w zakładach - zaczynają bowiem wtedy sami, na własną rękę murować i budować, czerpiąc z nowych technik zdobytych w dużych miastach. Korzystają zatem nie tylko z łatwego dojścia do materiałów, ale też z żywiołowo zdobywanych umiejętności - domy budują metodą "gospodarską”, a materiały „organizują" (nieformalnie pozyskują je z zakładów pracy). Powstające wtedy na wsi domy mają co prawda powtarzalny, geometryczny kształt, były to tzw. kostki, obecnie kojarzone z brzydotą PRL-u, ich popularność spowodowana była jednak nie tylko wymogami urzędników, dających zezwolenia na najprostsze, powtarzalne formy modernistyczne, ale przede wszystkim prostą konstrukcją, bez na przykład kosztownej i wymagającej materiałów więźby dachowej, co było ważne w sytuacji, kiedy budynki były

6 Zob. m.in. K. Szafraniec Polskie residuum systemowe, czyli pytanie o rolę wsi i chłopów w procesach przekształceń ustrojowych, "Kultura i Społeczeństwo" $2002 \mathrm{nr} 4$ 4 J. Wasilewski Społeczeństwo polskie...

7 Zob. m.in. M. Gomuła „Zastał Polskę drewnianq a zostawił murowanq...", czyli wpływ dekady gierkowskiej na życie społeczne wsi polskiej, praca laboratoryjna, Archiwum IEiAK UW, Warszawa 2004; zob. też E. Szpak Mentalność ludności wiejskiej w PRL. Studium zmian, Wydawnictwo Naukowe Scholar, Warszawa 2013, s. 42-43. 
wznoszone przez samych mieszkańców. W latach 60. i 70. ludzie ci budują sami, zatem eksperymentują z budową, a z samodzielnie robionych pustaków stawiają niemal wszystkie konstrukcje.

To w tamtym czasie jednak pojawiają się też zręby podmiotowości społecznej, wspólnej, choć zarazem ulokowanej w pojedynczych, wiejskich biografiach. W badaniach, które prowadziłem wraz z zespołem we wsiach pod Szydłowcem, okazało się, że miejsca takie jak ochotnicza straż pożarna, miejscowa szkoła, świetlica wiejska są ważne właśnie dlatego, że ogniskują nieformalną, oddolną aktywność organizacyjną. Te budynki stawiane w latach 6o. i 70. rękami ludzi, w ramach "czynu społecznego", mają symboliczne znaczenie. Okazuje się jednocześnie, że w ogóle „czyn społeczny” ma tam zupełnie inny sens niż ten powszechny, kojarzony z absurdalną, propagandową akcją państwa ludowego. „Czyny społeczne” opowiadane są z dumą i entuzjazmem, to raczej doświadczenie oporu i samostanowienia niż socjalistycznej podległości ${ }^{8}$. Aby zrozumieć ten charakter organizacji wiejskich jako inną, wartościową logikę społeczną, warto wskazać także na pewien nieformalny, zamknięty sposób współdziałania. Dobrym przykładem są właśnie działania ochotniczych straży pożarnych, wiejskich klubów sportowych, świetlic czy szkół’. Są to właściwie nieformalne, mające ciągłość historyczną instytucje społeczne, organizujące inaczej, ale bardzo skutecznie mieszkańców wsi. $\mathrm{Na}$ przykład w latach 9o. i później w OSP obowiązkowo biorą w niej udział wszyscy mężczyźni, wtedy często już trwale bezrobotni lub migrujący wahadłowo za dorywczą pracą, a straż stanowi dla nich źródło tożsamości i stabilizacji społeczno-egzystencjalnej. Weronika Najda, opisując wiejski klub sportowy „Hubal” we wsi Chlewiska ${ }^{10}$, także podkreśla, że jego funkcjonowanie wiąże się z bogatą sferą różnorodnych aktywności: od organizowania się piłkarzy i działaczy klubu do organizowania się kibiców i rodzin piłkarzy ze wsi w gminie. Podobnie jest również w przypadku świetlicy we wsi Zaława (gdzie swoją siedzibę ma zresztą koło gospodyń wiejskich): świetlica jest częścią państwowej instytucji, powstała jednak dzięki działaniu społecznemu - sołtys

8 T. Pisarzewski Wspólnota wiejska - przemiany, w: Lokalnie: animacja kultury/community arts, red. I. Kurz, IKP UW, Warszawa 2008. W. Plińska Ochotnicza straż pożarna - klub kultury, w: Lokalnie: animacja kultury..., http://www. wpek.pl/pi/85047_1.pdf(20.12.2016). dolne tworzenie kultury. Perspektywa antropologiczna, red. P. Cichocki i in., IEiAK UW, Warszawa 2016. 
z przyjacielem znaleźli na złomowisku grzejniki, za pomocą których zrobiono ogrzewanie; własnymi siłami przebudowano także samo pomieszczenie. To, co ktoś mógłby uznawać za coś instytucjonalnego, „państwowego”, ma tutaj swój niezwykle silny komponent oddolny. Instytucje i ich zaplecze są tworzone przez ludzi, w ich wolnym czasie i to częściowo z materiałów, które uznalibyśmy za odpady. Instytucje państwowe są w ten sposób wypełniane oddolnie - to odzwierciedla pewien typ myślenia, z którym stoi w sprzeczności wszelka, zakładana często przez publicystów i badaczy, „roszczeniowość” wsi. Oczywiście mogą się tam ujawniać konflikty, kłótnie, rozgrywki, ale myślenie, że to instytucja państwowa ma nam coś dać, ma o coś dbać, że coś powinno być inaczej, jest raczej obce tym lokalnym sposobom ujmowania świata. Okazuje się zatem, że być może środowiska wiejskie tworzą własne, samorzutne, spontaniczne, nierozpoznane aktywności społeczne, które wypełniają na swój sposób obecną tam pamięć ostatnich dziesięcioleci, lata PRL-u i lata transformacji. Czas modernizacji lat PRL-u, państwo czasu socjalizmu, szczególnie lata 70., dla wsi, nie jest więc jedynie jakąś bezwładną, zewnętrzną siłą; przeciwnie, odsłania pewien nowy sens wydarzeń i doświadczeń ludzi ze środowisk wiejskich. Jest to już zupełnie inna historia ludzi wsi - rozwoju ich własnych umiejętności, wyobraźni technicznej, metod eksperymentowania z urządzeniami, oddolnego działania, wiejskiego aktywizmu.

\section{"Heteronimiczne przesunięcie" i alternatywne formy wyobraźni społecznej}

Z jednej strony mamy do czynienia z interpretacjami życia społecznego, które w miejscu wiejskich nieformalnych struktur samoorganizacji rozpoznają często pewien rodzaj defektu: krąg „znajomości”, ciasnych grup, nieregulowanych więzi. Są to interpretacje powstające w instytucjach akademickich, rządowych czy pozarządowych - i to te narracje cały czas wyznaczają kierunki myślenia i wprowadzają obowiązujące definicje życia społecznego i politycznego. Ale z drugiej strony można, jak sądzę, zbudować też perspektywę wręcz przeciwną, w której poszukiwane jest zjawisko myśli bardziej oddolnej, trudnej do pełnego uchwycenia, a może nawet, jak chciałby Antonio Gramsci, zmierzające do wysiłku „odzyskiwania” historii myśli społecznej - „dekolonizacji umysłów” (sformułowanie Nigeryjczyka Ngugi wa Thiong'o) ${ }^{11}$. „Ludzie - jak pisał zresztą Émile Durkheim - nie czekali na pojawienie się

11 E. Domańska Badania postkolonialne, w: L. Gandhi Teoria postkolonialna. Wprowadzenie krytyczne, Wydawnictwo Poznańskie, Poznań 2008, s. 159. 
nauki społecznej, by wytworzyć sobie idee prawa, moralności, rodziny, państwa, a nawet społeczeństwa, ponieważ bez tych idei nie mogliby się w życiu obejść"12. Jednak odzyskiwanie własnych, oddolnych artykulacji, zdekolonizowanych pragnień i aspiracji wydobywających się ze światów bardziej peryferyjnych często sprowadza też zagrożenia niweczące niemal całe wcześniejsze zamiary. Można powiedzieć, że ta walka o odzyskanie głosu oddolnego czy lokalnego wikła się wciąż we własne założenia, co wynika chociażby z tego, że sam podział na obiegi dominujące (kolonizujące) i zdominowane (skolonizowane), centralne i peryferyjne, „inteligenckie” i „ludowe” jest mocno problematyczny, a linie podziału i napięć pomiędzy dyskursami są bardzo płynne i wzajemnie mogą z siebie czerpać i wynikać. W ten sposób jednak to, co nieformalne i oddolne, w ogóle przykuwa tutaj szczególną uwagę. Można te procesy potraktować jako coś w rodzaju „heteronimicznego przesunięcia” (heteronymous shift) ${ }^{\mathbf{1 3}}$, by użyć terminu Alexeja Yurchaka, czyli pewnego społecznego aktu reprodukowania form instytucji społecznych i form państwa, ale z reinterpretacją znaczenia; to „przesunięcie” przekraczające nawet coś, co nazwane może być formą oporu, symulacji czy „markowaniem działania”, to raczej bardzo swoista kontynuacja społecznych ideałów „życia państwowego" (w badaniach Yurchaka - dawnego „życia radzieckiego”) ${ }^{\mathbf{1 4}}$, tyle że w oddolnej, spontanicznej formie, niegdyś niewidzialnej dla aparatu partyjnego, a obecnie wciąż szerzej nieznanej, niejawnej, trudnej do ujrzenia.

Przykładem może być sposób pamiętania i rozumienia przemian ostatnich kilkudziesięciu lat przez Elżbietę Szewczyk, jedną z przedstawicielek „historii broniowskiej myśli socjologicznej”15, projektu artystyczno-animacyjnego, rolniczą emerytkę, dawniej hodowczynię krów, wieloletnią radną. Jest to pewna oddolnie praktykowana teoria społeczna, wiedza nieustannie przebudowywana, wydobywana przy każdej rozmowie: opowieść Elżbiety

12 É. Durkheim Zasady metody socjologicznej, przeł. J. Szacki, PWN, Warszawa 1968, s. 46. Cyt. za: J. Szacki, Historia myśl socjologicznej, PWN, Warszawa 2002, s. 18.

13 Od heteronimu (gr.), czyli sytuacji, w której jeden wyraz, zapisywany w identycznej formie, może mieć zupełnie różne znaczenia. Zob. A. Yurchak Soviet Hegemony of Form: Everything Was Forever, Until It Was No More ,"Comparative Studies in Society and History" 2003 no. 3, s. 482-483.

A. Yurchak Soviet Hegemony of Form..., s. 480-510.

Zob. T. Rakowski Alternatywne historie myśli socjologicznej. Działania, imaginacje, pragnienia, w: Etnografia/animacja/sztuka, red. T. Rakowski, NCK, Warszawa 2013, więcej o Elżbiecie Szewczyk zob. tegoż Elżbieta Szewczyk i skok do królestwa wolności, w: Peryferie kultury. Szkice ofiarowane Profesorowi Rochowi Sulimie, red. R. Chymkowski i in., Wydział Polonistyki UW, Warszawa 2013. 
Szewczyk zaczyna się toczyć, powraca do początku, potem zatacza coraz większe koła, jest spójna, ale nieustannie powtarza pewne wątki. Można by uznać, że jest to droga myślenia, o której Roch Sulima pisał jako o „literaturze koniecznej", jak na przykład żarliwa artykulacja pojawiająca się w sytuacji pisania "do urzędu", obecna chociażby w podaniach, skargach, testamentach chłopskich ${ }^{16}$. W przypadku pani Elżbiety jest to rodzaj twórczości słownej, wyobrażeniowej i pamięciowej naraz, ale budowanej na potrzeby własnego świata, twórczości bardziej „na obstalunek” niż „na zbyt” (Piotr Bogatyriew i Roman Jakobson pisali tak o różnicy pracy folkloru i pracy literatury $\left.{ }^{17}\right)$. Zazwyczaj myśli jej krążą wokół drobnych gospodarzy i prawie zawsze opowiada o pouwłaszczeniowych gospodarstwach z Kongresówki, gdzie nie opłacało się trzymać koni czy maszyn. Tym, co ją więc fascynuje, są „wioski zwarte, dom przy domu”, gdzie „powstać musiały kółka rolnicze”. Kółka rolnicze, geesy, skupy na placu - były, jak przekonuje, tuż przed jej domem, w którym mieszka teraz z rodziną, sama zaś, wraz z mężem (pracował jako zawodowy kierowca), postawiła w latach 80. wzorcową, nowoczesną oborę, którą oglądamy nieustannie wprost przez okno, siedząc w dużej kuchni. Po drugiej stronie jej domu okna wychodzą już na drogę i zakrzaczone pola, ciągnące się aż do Pawłowa.

Jest to jednak miejsce, którego Elżbieta nienawidzi. „Tam teraz widzicie. Te krzaki" - mówi. To zarośnięte pole jest w jej wizji świata najsilniejszą chyba negacją tego, co być tam miało: placu wiejskiego i działającego skupu. Zakrzaczenie to coś, co uwiera Elżbietę, to coś, przeciwko czemu jako wieloletnia radna, zastępczyni wójta, członkini rady nadzorczej Rolmleczu walczyła przez całe życie. Zakrzaczenie wiąże się tu z pracą i z polityką pracy na wsi. Według tej wizji wieś zwarta, świętokrzyska czy południowomazowiecka, to zawsze będzie miejsce, gdzie nie tyle powstawać powinny wielohektarowe gospodarstwa, ile raczej przeważają i przeważać będą gospodarstwa małe i drobne. Mogą one mieć ledwie kilka krów (nawet jedną), ale przy działających kółkach rolniczych i spółdzielniach to już pozwala na ich funkcjonowanie. Ludzie, twierdzi pani Elżbieta, mogą sprzedać niewielkie ilości mleka, uzyskać podstawowe zapłaty, obrabiać drobne ziemie, pastwiska.,Wsie zaczynają działać!, to mleko - entuzjazmuje się Szewczyk - nie jest niepotrzebne, jest

Zob. m.in. R. Sulima Słowo i etos. Szkice o kulturze, Fundacja Artystyczna Związku Młodzieży Wiejskiej "Galicja”, Kraków 1992.

17 Zob. P. Bogatyriew, R. Jakobson Folklor jako swoista forma twórczości, w: P. Bogatyriew Semiotyka kultury ludowej, PIW, Warszawa 1975. 
najlepsze, najlepsze na rynek wewnętrzny". Tym, co przyszło na wieś wraz z przemianami lat 9o., jest zatem „zakrzaczenie”, ale tak naprawdę pod tym określeniem kryje się - jak wskazuje pani Elżbieta - „zniszczenie spółdzielczości. To stąd te krzaki". Wizję ma pełną - każda rozmowa jest właściwie kompletną opowieścią na temat drogi od działających kółek, do uprawianych, potrzebnych pastwisk, a następnie do pustych przestrzeni i pustych życiorysów zniechęconych, drobnych gospodarzy, pijących pod dawnym geesem. Ta utrata odsłania jednak wizję pracy właściwej, pełnej, pracy mleczarskiej. Przedstawiają ją obrazy wielości - wielości drobnych mleczarzy, „bańkowców", czyli tych, którzy dostarczają mleko w bańkach, którym opłaca się prowadzić drobne gospodarstwa. Ich przeciwieństwem, a przy tym powodem ich nieopłacalności są nowe gospodarstwa i nowe normy skupowanego mleka: to produkcja na wielką skalę, bycie „zbiornikowcem”, czyli posiadanie zbiornika chłodzącego mleko zaraz po udoju. Najlepsze mleko, podkreśla Szewczyk, to mimo wszystko mleko od "bańkowców”. Jednocześnie to ono właśnie "nie opłaci się, nie spełnia normy” - choć jest przecież „najlepsze na rynek wewnętrzny", daje zajęcie, pozwala na prace w gospodarstwie, niesie jakby ogólnospołeczne „uzdrowienie” („odkrzaczenie”).

Wizja Elżbiety jest wizją zarazem spójną i namiętną. Najistotniejsza jest tu chyba jednak pewna droga myślenia, pamiętania i działania, która nie mieści się w ramie pamięci zbiorowej. Jest to zupełnie inna perspektywa, która wnosi coś własnego, coś, co dzieje się poza głównym nurtem pamięci o PRL-u. Sądzę, że przede wszystkim wiedza taka może przekraczać różne sprzeczności układu centrum-peryferie i przeprowadzać nas w zupełnie inny świat - świat, który był udziałem wielu innych lokalnych postaci budujących swą wiedzę i swą osobną teorię społeczną. Jednak ten inny wymiar historii i tę odmienną formę budowania zbiorowej pamięci znajdziemy w wielu różnych przekazach, w tym na przykład, choć przesunięte mocno w swoich znaczeniach, w pracach artysty Daniela Rycharskiego i jego współpracownika Szymona Maliborskiego. Są to prace o charakterze eksperymentu społeczno-artystycznego. Przykładem może tu być Pomnik chtopa i jego szeroko znana podróż po Polsce, z północnego Mazowsza na południe, do Krakowa, z powrotem do Warszawy, do podlubelskich wsi i do samego Lublina. Pomnik ten to figura chłopa pełnego zgryzoty - siedzącego w pozycji Chrystusa Frasobliwego sołtysa Kurówka; pomnik naśladuje jednocześnie niezrealizowany projekt Albrechta Dürera, który miał upamiętniać XVI-wieczne bunty i wojny chłopskie. W tej figurze sołtys, Adam Pesta, siedzi właśnie jako były "bańkowiec", na pustej, bezużytecznej bańce po mleku, którą znalazł u niego 
na podwórku Rycharski - kiedy Pesta jeszcze miał krowę, odstawiał mleko w bańkach, w tym czasie pracował też w szkole jako palacz. To taka zatem figura - figura „bańkowca” - umieszczona na podnośniku skonstruowanym przez Stanisława Garbarczuka, artystę outsidera pochodzącego z wsi rodzinnej ojca Rycharskiego ${ }^{18}$, przyciągała w trakcie tej podróży spojrzenia, zwracała uwagę przyjeżdżających ludzi. Najważniejsze jednak, że wymagała włączenia się w rolniczą samoorganizację - przyczepę z figurą holowano ciągnikami ze wsi do wsi, dekorowano sprejami, malowano. Było to zatem jakby wpisanie chłopskiej, odmiennej historii w szerszą peregrynację po polskiej pamięci zbiorowej, obejmującą także miasta, w których pomnik stawał - na przykład w cieniu warszawskich drapaczy chmur (sąsiadujących z pawilonem Emilia, siedzibą MSN-u).W tym samym czasie rozpoczęła się również jeszcze inna akcja - projekt przeniesienia rozebranej wiejskiej chałupy, w której na skraju Kurówka lat swych dożywała samotna wiejska kobieta, i stworzenia w niej swoistego muzeum alternatywnych historii społecznych (dokładnie: Village People: Muzeum Alternatywnych Historii Społecznych). Ten dom, zmontowany jako metalowe rusztowanie pokryte płatami pleksi, z rozłożonymi na ziemi ceglanymi ścianami, „szczytami”, wypełniony znakami rolniczych protestów i surową twórczością samego Stanisława Garbarczuka, stanął na bulwarach krakowskich, naprzeciwko wzgórza wawelskiego. Nie można było niemal spojrzeć na to muzeum tak, by nie uchwycić w jednym polu widzenia współistnienia tego starego, pokruszonego wiejskiego domu i Wawelu.

Być może jednak jeszcze wyraźniej widać ten rodzaj pamięci w kontynuacji wspomnianych działań, którym było podjęcie się przez Rycharskiego zaprojektowania i wykonania dla rolników związkowców sztandaru męczennika, św. Ekspedyta - jest to sztandar z obrazem legionisty rzymskiego otoczonego wieńcem ognia, z krukiem u stóp („co masz zrobić jutro zrób dziś") i posągową twarzą samego artysty. Przekazanie działaczom rolniczej Solidarności sztandaru w Muzeum Sztuki Nowoczesnej w Warszawie stało się bardzo ważnym, choć kameralnym politycznym spotkaniem z udziałem niewielkiej grupki przedstawicieli walki o prawa rolników, z głośnym wznoszeniem przez przewodniczącego rolniczej Solidarności ze Stopnicy haseł typu „Jeszcze Polska nie zginęła”. Sztandar miał upamiętniać jednak szczególnie wydarzenie z 2013 roku, zapomniany akt samobójstwa ubogiego rencisty

18 Stanisław Garbarczuk był jednym z uczestników wystawy „Po co sq wojny na świecie?" Sztuka współczesnych outsiderów, Muzeum Sztuki Nowoczesnej, Warszawa, luty-maj 2016. 
z Kielc, będący protestem przeciw pozostawieniu samym sobie ludzi takich jak on: chorych, dorabiających, doświadczających biedy. Środowiska polityczne wsi stworzyły w ten sposób, w cieniu innych wydarzeń poświęconych patronowi, własny kalendarz historii. To o tym działacze mówili, a w maju 2015 roku postanowili podjąć w tej sprawie uchwałę - mieli ją ze sobą w Muzeum w dniu przekazania sztandaru (maj 2016). Powstaje tak znów zupełnie inna historia, pełna emocji, uobecniająca się w kameralnym performansie, istotna - jak wskazywali badacze historii oddolnej (mówionej) - właśnie dlatego, że tworzą ją ci, których życie nie jest na tyle politycznie znaczące, by je spisywać, "kronikować” i czynić z niego historię. Być może więc te historie przekazują rzeczy bardziej „prawdziwe”, ale w tym sensie, że ludzie je tworzący nie prowadzą żadnej dominującej polityki wiedzy i - by przywołać słowa Györgya Lukácsa $^{19}$ - jako pozbawieni znaczącej władzy „nie mają nic do stracenia, mówiąc prawdę".

\section{Aktualizujące się historie, alternatywne formy pamięci}

Nie sądzę, by historie alternatywne należało traktować jako ciche, bezgłośne czy zupełnie pozbawione przywilejów. W tym przypadku widać wyraźnie, że mogą to być takie eksperymenty, takie sposoby tworzenia wiedzy i w ogóle "twórczości koniecznej”, które budują skuteczne umocowania egzystencjalne i umiejętności osiągania celów. Idea „mówienia nieuwikłanego”, „mówienia prawdy" przez grupy marginalizowane, peryferyjne nie jest więc wystarczająco dobrą odpowiedzią na pytanie, dlaczego warto zwracać się w stronę tego, co oddolne, nieformalne, samorzutne. Chodzi bardziej o to, by ta inna forma pamiętania, powstająca wśród akcji, działań, druków, obrazów, wędrówki Pomnika chłopa mogła zostać potraktowana zupełnie poważnie, by na powrót jej zaufać. Chodzi również o to, by informacje o innych znaczeniach kulturowych, o innych doświadczeniach społeczno-biograficznych umieć uczynić wiarygodnymi danymi - na przykład przez ukontekstowienie sytuacji, powtarzalność rozpoznań. Do pewnego stopnia pomocna może być tu analogia do metodologicznej refleksji Dipesha Chakrabarty'ego ${ }^{20}$, zawartej

Cyt. za M. Songin Z podporzq̨dkowanego punktu widzenia. Roszczenia poznawcze klas podrzędnych, w: Humanistyka i dominacja. Oddolne doświadczenia w perspektywie zewnętrznych rozpoznań, red. T. Rakowski, A. Malewska-Szałygin, IEiAK UW, Warszawa 2011, s. 34. 
w jego znanym tekście o historiach podrzędnych. „Inne” historie obecne w przekazie ustnym, o których pisze Chakrabarty, dotyczą ludu Santalów w kolonialnych Indiach, grupy o pozycji podporządkowanej, choć rdzennej, w przeciwieństwie do brytyjskiej kolonialnej administracji. Jak się okazuje, przekazy tej ludności i jej wersje zdarzeń historycznych, motywacja do powstania przeciw aparatowi Korony Brytyjskiej są jednak zupełnie inne od typowo rozpoznawanych w studiach historyków - to na przykład logika dopuszczająca ingerencję sił pozaludzkich i nadprzyrodzonych. Nie są one traktowane jedynie jako głos oddolny, stłumiony - historia o powstaniu Santalów przeciw Brytyjczykom jest bardziej historią odmiennych epistemologii i odmiennych logik. Historia podrzędna i jej ustny przekaz są więc u Chakrabarty'ego nie tyle historią „inną", ile wkroczeniem na karty historii innego świata: widzi on oddolne, alternatywne historie jako gruzełki albo supły wybijające się spod owego europejskiego kontinuum przyczynowo-skutkowego - linearnej historii, rozumianej w świetle związanych ze sobą materiałów i faktów. Podrzędne przeszłości - pisze Chakrabarty - „są jak twarde supły, które wystają i zniekształcają gładko utkaną powierzchnię materiału"21.

W przypadku alternatywnych historii społecznych - muzeum Village People, innych wyobraźni czy projektu „broniowskich myśli socjologicznych" napotykamy, mam wrażenie, coś właśnie bardzo podobnego. Jest to bowiem taki rodzaj materiału historycznego, który niesie ze sobą opowieść nie tylko o jakiejś lokalnej kosmologii, innej ontologii zdarzeń, o sposobie budowania zmityzowanych obrazów, ale jest to także na pewnym poziomie opowieść o tym, , jak było", jak przebiegała historia w sensie realnego doświadczenia historycznego. Podejmuję zatem ryzyko stwierdzenia, że nieformalne, mówione, kontekstowe dane o przeszłości, wydobywane chociażby z rozmów etnograficznych czy projektów artystycznych mogą przynosić pewne wiadomości istotnie zmieniające obwiązującą wiedzę i tym samym ramy polskiej pamięci zbiorowej. Co więcej, postrzegam te oddolne, alternatywne i czasami buntownicze zespoły wiedzy jako wyjątkowo ważne elementy spajania, wiązania i rozumienia historii. Mówiąc jeszcze inaczej: uważam, że pamięć wykuwana w dominujących dyskursach historycznych bazuje na pisanych i interpretowanych wciąż dokumentacjach zdarzeń. Zawiera zatem w sobie coś w rodzaju przesunięcia w przeszłość, zdeponowania i określenia 
źródeł, i dopóki są to źródła przeszłe, dopóty dystans poznawczy zapewnia też pewne bezpieczeństwo myślenia, odnosi się do swoistego archiwum do przestrzeni odsunięcia, dystansu, manipulatywności, porównywalności danych. Historia buntownicza, inna czy alternatywna działa jednak właśnie zupełnie inaczej: mówi ona o tym, co jednoczasowe (coeval), obecne tu i teraz, rekonstruowane w inny sposób konieczny, pamiętany, niepełny, ale niezwykle intensywny.

O ile zatem w odniesieniu do przeszłości mamy zawsze do czynienia z „rekonstrukcją" dziejów na podstawie niepełnych źródeł, o tyle w tym przypadku już wyjściowo mamy w ogóle inne podejście do danych historycznych. Nie ma tam ani złudzenia „pełnego dostępu” do danych współczesnych, ani złudzenia niepełnego i pośredniego dostępu do tego, ,jak było" w przeszłości. Odsłania się natomiast bardziej świadomość ujmowania rzeczywistości jako aktów z jednej strony bazowych dla procesu budowania pamięci historycznej, z drugiej zaś - różnych, odmiennych, rysowanych w doświadczeniu teorii tego, ,jak było". Nie jest to przy tym jedynie głos dopominania się o historię mówioną czy o historie alternatywne i, jak u Chakrabarty'ego, „historie podrzędne”. Nie jest to wypełnianie istniejącej już mapy historii ani też archiwizowanie wypowiedzi świadków historii, tworzenie cyfrowych repozytoriów wiedzy mówionej - taka „archiwizacja” może bowiem prowadzić do neutralizacji tego, co pamiętane, czasem to wręcz pewna dewaluacja historii mówionej albo jako specyficznej metody, albo jako uzupełnienia/dodatku do wiedzy historyków. To zatem pamięć alternatywna jest tutaj punktem wyjścia: relacja i spotkanie człowieka niosącego wiedzę transformacyjną, bardziej już jako "historię zaświadczającą" (witnessing history) niż jako „historię mówioną" (oral history). To „cząstka elementarna” historii mówionej - relacja z tego, ,jak było”, i co ma realne znaczenie.

To historie zmieniające, przebudowujące pamięć zbiorową, sens tego, co było, opisywane mogą być szeroko. W Broniowie, Załawie, Cukrówce, Ostałówku pod Szydłowcem odkryliśmy na przykład, że od trzech pokoleń, jeszcze od lat 70., mieszkańcy jeżdżą do prac w Europie Zachodniej w lunaparkach i wesołych miasteczkach, wynajmowani jako specjaliści od urządzeń mechanicznych i konserwacji mechanizmów - trwa to od socjalistycznych kontraktów dla pobliskich zakładów Rozmet aż po czasy dzisiejsze. Ta lokalna historia specjalizacji widoczna jest chociażby w tym, że w wielu domach znajdziemy z dumą przechowywane albumy i foldery reklamowe prezentujące urządzenia, oświetlenia, rewie na lodzie i tym podobne, zainstalowane w miastach 
Niemiec, Szwajcarii czy Francji. Badania narracji byłych robotników stoczni gdyńskiej prowadzonych przez Piotra Filipkowskiego ${ }^{22}$ pokazują jeszcze inne historie: to prace nad konstrukcjami statków uznawanych za najlepsze na świecie, statków, którym inżynierowie i robotnicy nadawali imiona i traktowali jak autorskie prace, które dawały nawet w najgorszych latach pewne poczucie zbiorowego sukcesu i zbiorowego eksperymentu. W ten sam sposób odkryć można jednak głębokie związki emocjonalne robotników i inżynierów z olbrzymią fabryką ciągników Ursus, znaną w ostatnich dekadach PRL-u niemal na całym świecie, które uwidoczniły się w trakcie niezwykłych działań Jaśminy Wójcik ${ }^{23} \mathrm{w}$ czasie współtworzenia z byłymi pracownikami instalacji Traktora-hybrydy (wciąż pamiętana dokładna znajomość hal i infrastruktury została wykorzystana przy produkcji hybrydy).

Za każdym razem trafiamy tu na zręby historii zaświadczającej. Co istotne, o ile u Chakrabarty'ego takie alternatywne, ,podrzędne” przeszłości często są przeciwstawne dominującym narracjom historycznym, o tyle w omawianych tu przypadkach te formy pamięci nabierają jeszcze innego, mocnego znaczenia. Nie są jakimś uzupełnieniem, historią mówioną, samodzielnie odnajdowaną i gromadzoną; nie są żadnym zneutralizowanym już na wstępie źródłem historycznym. Mają moc dowodzenia, że „było inaczej”, co więcej, że to „inaczej” pozwala też na rozwijanie niezależnych systemów myśli społecznej i alternatywnej wyobraźni społecznej - i to nie tylko w rozumieniu antropologicznym. Nie tyle tworzą twarde supły wystające spod gładkiego płótna, ile bardziej mają strukturę jeżowca: ostre kolce tych danych, tych zdarzeń, tej pamięci rozpruwają, przecinają płótno historii i wymagają zszycia go na nowo. To zatem kwanty wiedzy, które budują inny, alternatywny ciąg przyczynowo-skutkowy. Alternatywny w tym znaczeniu, że zmuszają do odkształcenia się całej perspektywy i do ponownego wykonania pracy nad pamięcią zbiorową, nad tym, co powstaje i co pozostaje jako historia. Odkształcają i przebudowują rozumienie tego, co było, i tego, co jest, a przede wszystkim tego, jak obie te sfery są ze sobą powiązane. W ten sposób powstaje coś nowego - nowe formy pamięci historycznej, budowanej na aktualizujących się

22 Z wystąpienia konferencyjnego P. Filipkowskiego Czy możliwa jest transformacyjna historia mówiona? O wstępnych trudnościach badania historii stoczni gdyńskiej w perspektywie oddolnej, konferencja PTL "Jaka refleksja o kulturze dzisiaj potrzebna? Wyzwania, dylematy, perspektywy", Wrocław 22-23.09.2016. 
doświadczeniach, na zaświadczających źródłach. Będzie to taka forma pamięci, która nie umie inaczej opowiedzieć o przeszłości, jak o nieustannie wyłaniającej się właśnie, zupełnie innej historii.

\section{Abstract}

\section{Tomasz Rakowski}

UNIVERSITY OF WARSAW

Ethnography, Memory, Experiment: Towards an Alternative Social History

Research on the self-organization and creative potential of rural communities in Poland suggests several decades of unrecognized conflicts of knowledge and social identity. This article demonstrates how work that is experimental both ethnographically and artistically can help reveal unfixed or absent elements of Polish identity conducted in contemporary village spaces. Rakowski suggests that ethnographic and artistic work can uncover unfixed cultural memories, enabling a completely new perspective on the formation of Polish society. This process paints a different, alternative social history, and at the same time it suggests a new perspective on issues of citizenship, social subjectivity and our understanding of history in a theoretical and methodological sense.

\section{Keywords}

social history, memory, experiment, village, ethnography, art 